are several published reports, although not exactly on Euglena, which show that blue-green algae, such as Microcystis, Anabaena, Aphanizomenon, which are also abundant in Wascana Lake, are known to produce substances that are toxic to some of the associated flora and fauna. Although there is not much convincing evidence to show that Euglena produces substances of the toxic type, it is possible that it could. Active research in this direction is phenomenally slow.

Euglena and some blue-green and green algae are known to be good indicators of pollution. They can thrive well in ponds and lakes containing high concentrations of organic and inorganic substances which could be inhibitory to the normal growth and development of other organisms. They are known to grow successfully on sewage where there is high depletion of oxygen, and also in other polluted areas caused by mine wastes. In view of all the evidence at hand, one should undoubtedly be concerned with the "red tide" of Euglena in Wascana Lake. There are also many other green and blue-green algae that may have contributed directly or indirectly to the supposedly polluted areas of Wascana Lake.

Although there is circumstantial evidence showing that Wascana Lake, at least in areas where Euglena redtide was noticed, is polluted, still we are not certain as to the type of pol- lution, whether it is formed as a result of natural causes within the lake itself and/or of man's intervention in some way. In nature we always recognize the death of larger consumers, such as birds, fish, etc., and attribute it to pollution. The death of consumers may be due to several factors: the algae by themselves may be toxic or they may release toxins into the environment and bring about mortality among both producers and consumers that live there. In view of our limited knowledge of the facts of pollution, serious efforts should be made to study intensively various aspects of the biology and biochemistry of the flora and fauna of Wascana Lake with particular reference to the producers such as algae and other micro-organisms. A detailed study of the environment in which such organisms live is also imperative. In regard to the red tide of Euglena, it is important to determine the internal and external factors that stimulate phenomenally the growth and development of the alga.

Considerable time, effort and money should be expended to carry out detailed biological investigations of Wascana Waterfowl Park and other adjacent areas. The results of such work could not only be exemplary for the prairies but could also help solve the problem of fresh-water lake pollution. Work of this sort may also give some clues that would be significant enough to effect proper measures of pollution control.

\title{
NEW OR UNUSUAL PLANT RECORDS FOR SASKATCHEWAN, 1969
}

\section{by John H. Hudson, 81 Morris Drive, Saskatoon}

This summer I was given material of a Silene which appears to be $S$. conoidea L. It was collected July 14 on the farm of Mrs. P. Bayoff, 3 miles S. of Verigin, when it had been growing as a weed in a barley field. As I did not see the plant alive, I shall not try to describe it; a description will be found in Boivin, Vol. 2, p. 94. He reports it from Lacombe, Alberta. A question may be asked about rare weeds of European origin like this; are they recent introductions (in which case they'll spread) or have they been with us since the early days of settlement, but aren't very aggressive?

I found Naias flexilis (Willd.) Rostk. \& Schmidt on August 10, 1969, in Pike Lake just west of the public 
beach. It is very rare in Saskatchewan, the only sheet in the Fraser Herbarium came from Great Sandy Lake (Hanson Lake Road). As to recognition, it is one of those limp submerged aquatics, in this case an annual rooted to the bottom, with opposite serrate linear leaves and inconspicuous oblong fruits some $2 \mathrm{~mm}$. long sessile and singly in the leafaxils. The point about this finding is that W. P. Fraser and students botanized Pike Lake thoroughly in the 1930's and did not get it. The plant is not all that inconspicuouschunks break off and are washed up on the beach, thus announcing its presence to those who are lookingand I do not think Fraser could have missed it. The alternative explanation is that Najas has come in since, perhaps since Pike Lake was made a provincial park. It is common in Eastern Canada.

Buchloe dactyloides (Nutt.) Engelm., the Buffalo Grass of the American short-grass plains, I had the good luck to find at Estevan, August 4, 1957 (Blue Jay 16, 20-21, 1958), as the first record in Saskatchewan. Another colony turned up this summer, also at Estevan, on SW 1/4 30-28 W2, some 2 miles NNW of the earlier discovery. This lot was growing around a stony depression on clayey prairie, of the sort which holds water only a few weeks in spring and soon dries up leaving cracked clay carrying a sparse annual vegetation rather than an aquatic flora of any sort. Associated species were Polygonum aviculare (native form), Plantago elongata, Schedonnardus, Poa secunda. Geologically the site was thin $\left(5^{\prime}-10^{\prime}\right)$ till over grey sandy clay of the Estevan beds of the Ravenscrag formation. The point is, the Buchloe was not growing in climax grassland at all but on a site, though usually dry, subject to just enough flooding to make the life of climax grasses like Stipa, Koeleria, Bouteloua, etc. impossible. The influence of bedrock shales may also play a part in rendering the soil more barren and thus making life tougher for climax grasses. The earlier location, SW $1 / 4$ 17-2-8 W2, a dry gumbo flat on the bottom of a valley tributary to the Souris River, also possessed the properties of rare flooding and bedrock shale influence. This restriction of Buchloe to a habitat which is effectively disturbed is doubtless due to being at the edge of its range, where it can survive only if freed of some of the competition. Further south it is a member, a dominant member, of a short-grass prairie community.

As an irrelevant sideline, the pothole in question had a little water in it on July 22 because of recent heavy rains. My attention was drawn to the Buchloe and its habitat by our truck getting stuck in this low gumbo spot, whereas we'd been passing over climax prairie, sodden though it was, without difficulty.

\section{CROCUS NOTES FROM DAWSON CREEK}

\section{By Dorothea Horton Calverley, Dawson Creek, B.C.}

The article on the Crocus Anemone in the September 1969 Blue Jay prompts me to add a note or two.

The super-abundance of the crocus in the spring of 1969 extended also into the Peace River country. Whole hillsides in the vicinity of Dawson Creek and out into the foothills of the Pine Valley gave from a distance the appearance of a scarf of delicate blue-orchid having been flung over them. Old-timers said that never before had anything like it been observed.

Whether the fact that the winter of 1968-69 was the coldest in memory had anything to do with it is an interesting question. During the two previous springs untimely and exceedingly heavy frosts in mid-May, after warm spells in April, froze even these super-hardy flowers so that, except in very few places, they produced no seeds. This year's flowering 